\title{
Coinfection by HTLV-I/II is associated with an increased risk of strongyloidiasis and delay in starting antiretroviral therapy for AIDS patients
}

\section{Authors}

Brites $\mathrm{C}^{1}$

Goyanna $\mathrm{F}^{1}$

França LG ${ }^{1}$

Pedroso $\mathrm{C}^{1}$

Netto EM ${ }^{1}$

Adriano $S^{1}$

Sampaio ${ }^{1}$

Harrington Jr W²

${ }^{1}$ Universidade Federal da Bahia, Salvador, Bahia, Brazil

${ }^{2}$ University of Miam School of Medicine, FL, USA
Submitted on: 03/08/2010 Approved on: 06/10/2010

\section{Correspondence to:}

Carlos Brites

Laboratório de Pesquisa em Infectologia-Virologia Rua João das Botas, SN, Canela - Salvador, Bahia, Brazil

CEP-40110-160

Phone: 55-71-32354901

Fax: 55-71-32472756

crbrites@ufba.br

We declare no conflict of interest

\begin{abstract}
Objective: To compare the clinical characteristics and outcomes of HIV-1-HTLV-1 coinfected patients, in Bahia, Brazil. Methods: Retrospective, comparative study. Results: Among a total of 123 consecutive HIV infected patients, 20 men $(20.6 \%)$ and 6 women $(23.1 \%)$ had detectable antibodies against HTLV-I/II. The major risk factor associated with coinfection by HTLV was intravenous drug use $(57.7 \%$ of coinfected patient versus $9.2 \%$ of HTLV seronegative patients, $\mathrm{p}<0.0001)$. Coinfected patients had higher absolute lymphocyte counts $(1,921+762$ versus $1,587+951, p=0.03)$. Both groups of patients had similar means of CD4+ and CD8+ cell counts. However, among patients with AIDS CD4+ cell counts were significantly higher among those coinfected with HTLV-I/II ( $292 \pm 92$ cells $/ \mathrm{mm}^{3}$, versus $\left.140 \pm 177 \mathrm{cells} / \mathrm{mm}^{3}, \mathrm{p}=0.36\right)$. The frequency and type of opportunistic infections were similar for both groups, but strongyloidiasis and encephalopathy were more frequently diagnosed in coinfected patients $(\mathrm{p}<0.05)$. On the other hand, patients coinfected with HTLV-I/II received significantly less antiretroviral therapy than singly infected by HIV-1. Conclusion: Coinfection by HTLV-I/II is associated with an increased risk of strongyloidiasis for HIV patients. Higher CD4 count may lead to underestimation of immunodeficiency, and delay to initiate antiretroviral therapy.
\end{abstract}

Keywords: HIV; HTLV-I/II; coinfection Strongyloidiasis; CD4/CD8.

[Braz J Infect Dis 2011;15(1):6-11] @Elsevier Editora Ltda.

\section{INTRODUCTION}

The human immunodeficiency virus type-I (HIV-1) is the causative agent of the acquired immunodeficiency syndrome (AIDS). Human T-cell leukemia/lymphoma virus type I (HTLV-I) is conclusively associated with adult T-cell leukemia/lymphoma (ATLL), and tropical spastic paraparesis/HTVL-associated myelopathy (TSP/HAM). The role of HTLV-II infection as a cause of disease is still controversial. ${ }^{1-5}$ These infectious agents all share a similar pattern of transmission. The established routes of infection are sexual, parenteral (blood transfusion, needle sharing or percutaneous exposure), and vertical (congenital or via breastfeeding). ${ }^{6-11}$ Coinfection with these two distinct retroviruses has been frequently reported in the last few years. ${ }^{12-16}$

There is some evidence suggesting that double infection by HIV-HTLV may alter the clinical and laboratory course of AIDS, but the real impact of coinfection on clinical presentation and outcome of AIDS patients remains to be determined. ${ }^{17-19}$
Bahia, a northeastern state of Brazil, is an endemic area for HTLV infection. A recent report showed a prevalence rate of $1.8 \%$ of HTLV-I/II antibodies among the general population..$^{20}$ The reported incidence of AIDS cases in Salvador, the capital city of Bahia state, is $16.3 / 100,000$ inhabitants. ${ }^{21}$ In a previous, cross-sectional study of $895 \mathrm{HIV}$-infected patients we detected a rate of coinfection by HTLV-I/II of $16.7 \%{ }^{16}$

This study was conducted in order to identify potential differences in the clinical evolution of HIV infected patients with or without HTLV-I/II coinfection, as well as to ascertain the impact of coinfection on the surrogate markers of HIV infection. Since highly active antiretroviral therapy (HAART) has dramatically modified the natural course of HIV infection, we retrospectively evaluated patients diagnosed before the HAART era. 


\section{MATERIAL AND METHODS}

\section{Patient population}

A total of 123 consecutive patients seen at the AIDS clinics of the Hospital Universitário Prof.EdgardSantos, in Salvador,Brazil,during the years of 1994 and 1995, were selected. To be eligible for the study, patients had to have a Western blot (WB)-confirmed infection by HIV-1, a previous test for HTLV-I/II antibodies (or stored serum sample), and a follow-up period of more than 6 months. The period of time was chosen in order to evaluate the impact of coinfection among patients before triple antiretroviral therapy was introduced as the standard of care for Brazilian patients with AIDS. Information on age, gender, route of transmission of retroviral infection, date of diagnosis, and clinical stage, both at the time of diagnosis and at the final evaluation were obtained from medical records or directly from the physicians responsible for the patients care. Clinical course, including the frequency and type of opportunistic infections (OI) or malignancies, use of antiretroviral drugs, the duration of therapy, and duration of follow-up was also recorded. The 1993's CDC revised classification was used for disease staging. All data were retrospectively collected from patients' medical charts.

Laboratory data used for comparison between the two groups were CD4 and CD8 cell counts, hemoglobin levels, and absolute number of lymphocytes. Two independent reviewers, who were blinded to the results of HTLV-I/II serology, performed data collection.

\section{Serology tests}

Screening for HIV-1 antibodies was performed by EIA (Genetic Systems, Seattle, WA) and confirmed by WB (Cambridge-Biotech, Rockville-MD). Antibodies against HTLV-I/II were detected using an EIA kit (Coulter Corporation, Hialeah, FL), and confirmed with WB (Fujirebio, Tokyo, Japan). The reactive samples (presence of any band on $\mathrm{WB}$ ) were then retested with a synthetic peptide-based ELISA (Coulter Select - Coulter Corporation) and by a WB (Diagnostics Biotechnology, Singapore) containing envelope recombinant proteins (rgp46-I and rgp46-II), which allows for the discrimination between HTLV-I and II infection. ${ }^{22-24}$

\section{Statistical analysis}

Descriptive statistics were calculated and proportions were compared by calculating odds ratio (OR) and estimating 95\% confidence intervals (CI) by the Cornfield method. Yates-corrected chi-square analysis was used to measure associations and calculate 2-tailed $P$ values. Means were compared using Student's $t$ test, and the Kruskal-Wallis test, when applicable. All calculations were performed by using EPIINFO 6.01b.

\section{RESULTS}

Medical records were reviewed for 123 patients (97 male), who fulfilled the inclusion criteria for the study. Twenty men (20.6\%) and 6 women (23.1\%) had detectable antibodies against HTLV-I/II (Table 1). Median follow-up time was 16

Table 1. Frequency of episodes of diagnosed infections according to the serological status for HTLV-I/II infection

\begin{tabular}{lcccc}
\hline & \multicolumn{3}{c}{ Infection HTLV serology } \\
\cline { 2 - 5 } & Negative & HTLV-I & HTLV-II & $\boldsymbol{P}_{\text {value }}$ \\
\hline P. jiroveci pneumonia & 20 & 1 & 1 & 0.3 \\
\hline CNS toxoplasmosis & 14 & 5 & - & 0.8 \\
\hline Oral candidiasis & 146 & 15 & 1 & 0.2 \\
\hline Esophageal candidiasis & 17 & 1 & 1 & 0.4 \\
\hline Tuberculosis & 37 & 10 & 1 & 0.8 \\
\hline Strongyloidiasis & 2 & 3 & 1 & 0.04 \\
\hline CNS cryptococosis & 2 & 0 & 1 & 0.8 \\
\hline Recurrent herpes & 31 & 2 & 1 & 0.4 \\
\hline CMV & 10 & 2 & 0 & 0.9 \\
\hline Kaposi's sarcoma & 9 & 1 & 0 & 0.8 \\
\hline Bacterial infections & 119 & 26 & 1 & 0.3 \\
\hline Cryptosporidiasis & 6 & 0 & 0 & 0.6 \\
\hline Isosporiasis & 4 & 1 & 0 & 0.9 \\
\hline Diarrhea & 178 & 25 & 5 & 0.3 \\
\hline Peripheral neuropathy & 5 & 2 & 0 & 0.8 \\
\hline Herpes zoster & 12 & 4 & 1 & 0.8 \\
\hline Encephalopathy & 1 & 2 & 0 & 0.04 \\
\hline
\end{tabular}

"Pvalue comparing negative and positive patients for HTLV-I/II antibodies. 
Table 2. Mean age and gender distribution for HIV-1 infected patients according to their serology results for HTLV-I and HTLV-II

\begin{tabular}{|c|c|c|c|c|c|}
\hline & \multicolumn{4}{|c|}{ HTLV serology results } & \multirow[b]{2}{*}{$P$ value } \\
\hline & Negative & HTLV-I & HTLV-II & HTLV-I/II & \\
\hline Age (mean \pm sd) & $33.2 \pm 8.8$ & $33.5 \pm 7.4$ & $35.5 \pm 11.1$ & 33 & 0.9 \\
\hline \multicolumn{6}{|l|}{ Gender } \\
\hline Male & 77 (79\%) & 17 (81\%) & 0.3 (75\%) & 0 & 0.3 \\
\hline Female & 20 (21\%) & 4 (19\%) & 0.1 (25\%) & $1(100 \%)$ & \\
\hline Total & 97 & 21 & 04 & 01 & \\
\hline
\end{tabular}

months (range 6-56 months). The mean age was significantly higher for men as compared to women $(34.5 \pm 8.1$ and $29 \pm 8.8$ respectively, $P=0.002$ ) but there was no difference between the mean age for HTLV-positive and negative patients (Table 2 ).

Risk factors for coinfection: the major risk factor associated with coinfection by HTLV was intravenous drug use (IVDU). Among HTLV seropositive patients, 57.7\% had a history of IVDU as the risk behavior for acquiring retroviral infections, compared to $9.2 \%$ among patients without HTLV coinfection $(P<0.0001)$. Infection by HTLV-I/II was not associated with blood transfusion, sexually transmitted diseases (STD), or sexual behavior (Table 3).

Clinical characteristics: at the time of the first visit to the clinic, 73 (59.3\%) patients were asymptomatic, while the remaining 50 patients had an established diagnosis of AIDS (category C by CDC criteria). The frequency of episodes of OI diagnosed during follow-up were compared according to the serological results for HTLV-I/II infection: there was no difference in the overall frequency of

Table 3. Risk factors for acquisition of retroviral infection among singly and dually infected patients

\begin{tabular}{lccccc}
\hline Risk factors & Negative HTLV-I & HTLV-II & HTLV-I/II & $\begin{array}{c}\boldsymbol{P} \\
\text { value* }^{*}\end{array}$ \\
\hline $\begin{array}{l}\text { Blood } \\
\text { transfusion }\end{array}$ & 0.5 & 0.1 & 0.1 & 0.1 & 0.4 \\
\hline IVDU & 0.9 & 12 & 0.3 & - & $<0.0001$ \\
\hline $\begin{array}{l}\text { Homosexual } \\
\text { activity }\end{array}$ & 45 & 10 & - & - & 0.2 \\
\hline $\begin{array}{l}\text { Previous STD } \\
\text { Sex with } \\
\text { prostitutes }\end{array}$ & 0.2 & 0.1 & - & - & 0.9 \\
\hline $\begin{array}{l}\text { None of the } \\
\text { above }\end{array}$ & & 10 & - & - & NS \\
\hline
\end{tabular}

IVDU, intravenous drugs user; STD, sexually transmitted diseases; NS, nonsignificant.

${ }^{\text {" }} P$ value comparing negative and positive patients for HTLV-I/ II antibodies. The total may exceed the sample size, due to positive history for more than one risks in the list.
OI for both groups, but strongyloidiasis was diagnosed in 4/26 coinfected, compared to $2 / 97$ in singly infected patients $(\mathrm{OR}=8.55 ; 95 \% \mathrm{CI}: 1.21-73.62, P=0.02$, Fisher exact test). In addition, two episodes of encephalopathy were diagnosed during the study period in HTLV-positive, but no case was detected among singly infected patients $(P=0.04$, Fisher exact test $)$.

\section{Laboratories results}

Hemoglobin levels were similar for both singly (11.9 \pm $2.2 \mathrm{~g} / \mathrm{dL})$ and doubly infected $(12 \pm 2.3 \mathrm{~g} / \mathrm{dL})$ patients $(P>0.05)$.

Patients coinfected by HTLV-I/II had absolute lymphocytes counts significantly higher than those infected by HIV-1 alone $(1,921 \pm 762$ versus $1,587 \pm 951$, $P=0.03)$. However, when they were stratified by clinical status, asymptomatic patients presented a similar number of lymphocytes, regardless of their HTLV-I/II serology status, while coinfected, symptomatic patients, had significantly higher lymphocyte counts (887 \pm 515 cells $/ \mathrm{mm}^{3}$ versus $1,687 \pm 731$ cells $/ \mathrm{mm}^{3}, P=0.02$, Kruskal-Wallis test).

A total of 75 patients had at least one available CD4 and CD8 counts. Mean CD 4 and CD8 cells counts were similar in both groups of patients $(P=0.07$, and $P=0.4$ for each mean count, respectively, Kruskal-Wallis test). However, coinfected patients diagnosed with AIDS at the time of their first visit had a mean CD4 count $(292 \pm 92$ cells $/ \mathrm{mm}^{3}$ versus $149 \pm 178$ cells $/ \mathrm{mm}^{3}, P=0.03$, KruskalWallis test), absolute lymphocyte counts significantly higher. Coinfected patients who developed AIDS during follow-up also had higher baseline CD4 count (679 \pm 247 cells $\left./ \mathrm{mm}^{3}\right)$, than singly infected patients $(303 \pm$ 249 cells $/ \mathrm{mm}^{3} ; P=0.07$, Kruskal-Wallis test). This difference was not observed for patients who remained asymptomatic throughout the study period (525 \pm 270 cells $/ \mathrm{mm}^{3}$ versus $532 \pm 261$ cells $/ \mathrm{mm}^{3}$ for HTLV negative and positive patients respectively $P=0.9$, KruskalWallis test). Since the study included patients followed before viral load tests were available, this information was not analyzed. Table 4 summarizes the laboratory results. 
Table 4. CD4+, CD8+ and lymphocyte counts (mean \pm SD) of patients according to their HTLV serology

\begin{tabular}{|c|c|c|c|c|c|c|}
\hline \multirow{2}{*}{$\begin{array}{l}\text { Laboratory } \\
\text { Values/clinical }\end{array}$} & & \multicolumn{5}{|c|}{ HTLV serology } \\
\hline & & Negative & HTLV-I & HTLV-II & HTLV-I/II & $P$ value* \\
\hline Status & $\mathrm{n}$ & 102 & 25 & 0.4 & 0.1 & \\
\hline Symptomatic & 50 & & & & & \\
\hline CD4 cell counts & 25 & $140 \pm 177$ & $292 \pm 92$ & - & - & 0.036 \\
\hline CD8 cell counts & 25 & $695 \pm 403$ & $839 \pm 537$ & - & - & 0.6 \\
\hline Lymphocytes & 50 & $887 \pm 515$ & $1,687 \pm 731$ & - & - & 0.02 \\
\hline Asymptomatic & 73 & & & & & \\
\hline CD4 cell counts & 50 & $434 \pm 281$ & $537 \pm 269$ & 504 & 832 & 0.5 \\
\hline CD8 cell counts & 50 & $1,300 \pm 883$ & $797 \pm 308$ & 465 & 1,965 & 0.1 \\
\hline Absolute lymphocyte count & 72 & $2,013 \pm 912$ & $2,257 \pm 835$ & $1,845 \pm 630$ & 2,255 & 0.8 \\
\hline All patients & 123 & & & & & \\
\hline CD4 cell counts & 75 & $334 \pm 284$ & $432 \pm 237$ & 504 & 832 & 0.2 \\
\hline CD8 cell counts & 75 & $1,112 \pm 813$ & $810 \pm 339$ & 465 & 1,965 & 0.2 \\
\hline Absolute lymphocyte count & 123 & $1,563 \pm 952$ & $958 \pm 816$ & $1,638 \pm 490$ & 2,255 & 0.1 \\
\hline
\end{tabular}

$P$ values were calculated by Kruskal-Wallis test, and compare HTLV I/II negative and positive patients.

"Only 50 patients had available CD4 cell counts.

Progression to clinical disease during the followup period was similar for singly and coinfected patients $(24 / 60$ and $3 / 13$, respectively, $\mathrm{RR}=0.58$; CI 0.20 - $1.63 P=0.3)$. Use of antiretroviral drugs was more frequent among patients infected by HIV-1 alone (64.3\%) compared to those coinfected by HTLV-I/II (42.3\%) ( $P=0.04$, Yates corrected). This difference was more evident when we analyzed patients without a clinical picture of AIDS (non-category C disease): only $16.4 \%$ of coinfected patients were on antiretroviral therapy, in contrast to $51 \%$ of singly infected patients $(\mathrm{RR}=0.23 ; 95 \% \mathrm{CI}: 0.06-0.97 \mathrm{P}=0.04$, Yates corrected $)$.

\section{DISCUSSION}

Chronic infection by HIV is associated with immunodeficiency, caused by progressive CD4 lymphocyte depletion. Infection by HTLV-I may also be related to some degree of perturbation of the immune response among patients that harbor the virus, but usually do not exhibit clinical symptoms. ${ }^{25}$

While there is evidence suggesting that coinfection by HIV-HTLV viruses may modify the clinical and laboratory findings during the course of HIV infection, the lack of conclusive studies leaves the clinical impact of HTLV infection on HIV infected patients open to controversy. The present report provides additional support for the contention that patients harboring HIV and HTLV may present a modified clinical course of the HIV infection, characterized by a higher frequency of some clinical events.
The demographic characteristics for singly and doubly infected patients were comparable in this report. In contrast, a previous, larger study, detected a higher prevalence of HTLV-I coinfection among women, in Bahia. ${ }^{26}$ This discrepancy may be due to the smaller sample size of this work, which probably lacked sufficient power to detect differences in coinfection rates by gender (only 6 women were coinfected).

Surrogate markers for HIV infection showed a distinct pattern for singly and doubly-infected patients. The absolute lymphocyte counts were quite different in the two groups, with higher counts among HTLV coinfected patients. Similar number of lymphocytes in asymptomatic patients in both groups suggests that lymphocyte depletion occurs more slowly in coinfected patients during the course of HIV infection.

The analysis of CD4 cell count provided a similar picture. Asymptomatic patients had comparable counts of CD4 cells, but in contrats it was higher among coinfected patients presenting with clinical disease. CD8 cell counts were not related to the status HTLV infection, regardless of the patient's clinical status. Similarly, hemoglobin levels were comparable in both groups.

The frequency of $S$. stercoralis OI was significantly higher among coinfected patients, as it was for encephalitis without other identifiable etiology. Infection by HTLV-I has been associated with higher risk for $S$. stercoralis parasitism in HIV-negative patients. ${ }^{27-30}$ In a previous report, we also detected higher prevalence of S. stercoralis infection in 
HIV-positive patients, compared to seronegatives. ${ }^{31}$ The present report provides evidence that this association in HIVHTLV coinfected patients is even higher than in HIV-1 singlyinfected individuals.

The association between coinfection and encephalopathy is less clear: HTLV-I infection is associated with TSP/ HAM, a clinical entity characterized by signs and symptoms of myelopathy, but displaying some evidence of brain involvement, such as perivascular infiltrates, demyelinization, and white matter destruction. In addition, other severe involvement of central nervous system has been reported. ${ }^{32-35}$ Unfortunately, the retrospective design of the present study did not allow to clarify the exact cause of death of these two patients.

The rate of clinical evolution from asymptomatic infection to AIDS during the follow-up period was similar for both groups. However, the use of antiretroviral drugs was more frequent among singly-infected patients suggesting that the abnormalities in the number of lymphocytes and the CD4+ count induced by HTLV coinfection may delay the initiation of antiretroviral therapy in coinfected patients, as predicted by Schechter $e t$ al. in a previous report. ${ }^{15}$ Since CD4 cell count is still the main marker to define the best moment to start antiretroviral therapy and/or prophylaxis for OI, this fact may add a clinically relevant problem to physicians, when attending patients in endemic areas for these two agents.

The finding that cell subsets count is similar among asymptomatic patients, but significantly different among those with clinical symptoms suggests that the decrease in CD4 cell counts occurs later in the evolution of coinfected patients. Nonetheless, the higher CD4 cell counts do not provide any immunological benefit. It is likely that immunological changes secondary to the progression of HIV infection may also be affected, or may modify the lymphoproliferative response that usually follows HTLV infection. However, the mechanisms and intensity of such immune modifications are still unclear.

Finally, the extent to which HIV/HTLV coinfection modifies clinical outcomes of HIV infected patients remains unclear. There are some evidence supporting the hypothesis that coinfection by these agents may modulate the clinical presentation of these individuals, with an increase in the frequency of some parasitic diseases, and of severe forms of scabies. ${ }^{31,36} \mathrm{In}$ addition, there are evidence supporting a potential impact of coinfection on survival, which was shorter for coinfected patients than for those infected by HIV-1 alone. ${ }^{37,38}$

Our study also presents some limitations, that could have influenced the results: first, the retrospective design may prevent definitive conclusions, although, since HAART is currently the standard of care for all patients in need of treatment we could not evaluate the impact of in- creased CD4 cell counts on physicians' decision on when to start therapy. On the other hand, the higher proportion of IVDU among coinfected patients could also be confounding factor of lower rate of antiretroviral treatment among coinfected patients. It could be true for asymptomatic patients, but our data showed that even patients with a clinical picture of AIDS had decreased chance of receiving therapy, which could not be explained on the basis of patients' risk behavior. It makes more sense to conclude that the discrepancy between CD4 cell count and clinical status was probably the factor that misled physicians in deciding the optimal time to start treatment. In addition, we did not have information on how many patients had stools examination performed for S. stercoralis parasitism, but in AIDS patients such parasite usually causes severe diarrhea and the stools examination routinely performed in these situations, making unlikely that a symptomatic patient not having had a proper diagnostic investigation.

Our results confirm previous studies reporting higher CD4 cell counts in coinfected patients, and suggest that such phenomenon may mislead physicians in the choice of the optimal time to start antiretroviral therapy. ${ }^{15,39}$ It can not be ruled out the delay in starting antiretroviral therapy as one of the potential explanation for the higher mortality detected among coinfected individuals caused by increased CD4 cell counts, rather than a direct effect of HTLV-I on AIDS progression. The increased frequency of $S$. stercoralis infection and encephalopathy also indicates that coinfection may modify the course of HIV disease. However, the available data provide only limited evidence and definitive answers will require larger, prospective studies.

\section{REFERENCES}

1. Kalyanaraman VS, Sarngadharan MG, Nakao T et al. Natural antibodies to the structural core protein (p24) of the human $\mathrm{t}$-cell leukemia (lymphoma) retrovirus found in sera of leukemia patients. Proc Natl Acad Sci. USA 1982; 79:1653-57.

2. Robert-Guroff M, Gallo RC. Establishment of an etiologic relationship between the human T-cell leukemia/lymphoma virus (HTLV) and adult T-cell leukemia. Blut 1983; 47:1-12.

3. Gessain A, Barin F, Vernanr JC, et al. Antibodies to human T-lymphotropic virus type I in patients with tropical spastic paraparesis. Lancet 1986; 2:99-100.

4. Bartholomew C, Cleghorn F, Charles W, et al. HTLV-I and tropical spastic paraparesis. Lancet 1986; 2:99-100.

5. Osame M, Usuku K, Izumo S, et al. HTLV-I associated myelopathy, a new clinical entity. Lancet 1986; 1:1031-2.

6. Ocochi K, Sato H, Hinuma Y. A retrospective study on transmission of adult $\mathrm{T}$ cell leukemia virus by blood transfusion. Seroconversion in recipients. Vox Sang 1984; 46:245-53.

7. Ando Y, Nakano S, Saito K, et al. Transmission of adult T cell leukemia retrovirus (HTLV-I) from mother to child: comparison of bottle-fed with breast-fed babies. Jpn J Cancer Res. 1987;78: 322-4. 
8. Bartholomew C, Saxiger WC, Clark JW, et al. Transmission of HTVL-I and HIV among homosexual men in Trinidad. JAMA 1987; 257:2605-8.

9. Kajiyama W, Kashiwagi S, Ikematsu H, et al. Intrafamilial transmission of adult T cell leukemia virus. J Infect Dis. 1986; 154:851-7.

10. Delaporte E, Peters M, Bardy JL, et al. Blood transfusion as a major risk factor for HTLV-I infection among hospitalized children in Gabon (Equatorial Africa). J Acq Immune Def Syndr. 1993; 6:424-8.

11. Blattner WA. Epidemiology of HYLV-I and associated diseases. In: Blattner, WA ed Human Retrovirollogy: HTLV. New York: Raven Press 1990; 251-65.

12. Bartholomew C, Blattner W, Cleghorn F. Progression to AIDS in homosexual men coinfection with HIV and HTLV-I Trinidad. Lancet 1987; 2:1469-1987.

13. Hattori T, Koito A, Takatsuli K, Ikematsu S. et al. Frequent infection with human T-cell lymphotropic virus type I in patients with AIDS, but not in carriers of human immunodeficiency virus type 1. J Acq Immune Def Synd. 1989; 2:272-276.

14. Gotuzzo E, Escamilla J, Phillips IA, Sanchez J, Wignall FS, Antigoni J. The impact of human T-lymphotropic virus type I/II infection on the prognosis of sexually acquired immunodeficiency syndrome. Archives of Internal Medicine 1992; 152:1429-52.

15. Schechter M, Harrison LH, Halsey NA, Trade G, Santino M, Moulton CH, Quinn TC. Coinfection with human T-cell lymphotropic virus type I and HIV in Brazil: impact on markers of HIV disease progression. JAMA 1994; 271:353-357.

16. Brites C, Harrington Jr W, Pedroso C, Netto EM, Badaró R. Epidemiological characteristics of HTLV-I and II coinfection in Brazilian subjects infected by HIV-1. Braz J Infect Dis. 1997; 43-48.

17. Zack JA, Cann AJ, Lugo JP, Chen ISY. HIV-1 production from infected peripheral blood T cell after HTLV-I induced mitogenic stimulation. Science 1988; 240:1026-9.

18. De Rossi A, Saggioro D, Calabró ML, Cenzato R, Chieco-Bianchi. Reciprocal activation of human T-lymphotropic viruses in HTLV-I transformed cells superinfected with HIV-1. J Acq Immune Def Synd 191; 4:380-385.

19. Lusso P, Lori F, Gallo RC. CD4-independent infection by human immunodeficiency virus type 1 after phenotypic mixing with human T-cell leukemia viruses. J Virol. 1990; 64(12):6341-4.

20. Dourado I, Alcantara LC, Barreto ML, da Gloria Teixeira M, Galvão-Castro B. HTLV-I in the general population of Salvador, Brazil: a city with African ethnic and sociodemographic characteristics. J Acquir Immune Defic Syndr. 2003 15;34(5):527-31.

21. Ministério da Saúde. AIDS - Boletim epidemiológico 2002, Ano XVI, N0 01. Semana epidemiológica 14 a 52.

22. Lal RB, Brodine S, Kazura J, Mbidde Katonga E, Yanagihara R, Roberts C. Sensitivity and specificity of a recombinant transmembrane glycoprotein (rgp 21) - spiked Western immunoblot for serological confirmation of human T-cell lymphotropic virus type I and II infections. J Clin Microbiol. 1992; 30(2):296-299.

23. Lipka JJ, Santiago P, Chan L, Reyes GR, Samuel KP, Blattner WA, Shaw GM, Hanson CV, Sninsky JJ, Foung SKH. Modified Western blot assay for confirmation and differentiation of human T-cell lymphotropic virus type I and II. J Infect Dis. 1991; 164:400-403.
24. Lipka JJ, Miyoshi I, Hadlol KG, Reyes GR, Chow TP, Blattner WA, Shaw GM, Hanson CV, Gallo D, Chan L, Foung SKH. Segregation of human T-cell lymphotropic virus type I and II infections by antibody reactivity to unique viral epitopes. J Infect Dis. 1992; 165:268-272.

25. Welles SL, Tachibana N, Okayama A, et al. Decreased reactivity to PPD among HTLV-I carriers in relation to virus and hematologic status. Intl J Cancer 1994; 56:337-40.

26. Brites C, Harrington Jr W, Pedroso C, Badaró R. HTLV-I/II infection among HIV-1 infected individuals in Brazil. The First National Conference on Human Retroviruses and Related Infections, Washington, DC, 1993.

27. Nakada K, Kokagura M, Komoda H, Hinuma Y. High incidence of HTLV antibody in carriers of Strongyloides stercoralis [letter]. Lancet 1984; 1:633.

28. Dixon AC, Yanagihara ET, Kwock DW, Nakamura JM. Strongyloidiasis associated with human T-cell lymphotropic virus type I infection in a nonendemic area. West Indian J Med. 1989; 151:410-3.

29. Robinson RD, Lindo JF, Neva FA, et al. Immunoepidemiologic studies of Strongyloides stercoralis and human T lymphotropic virus type I infections in Jamaica. West Indian Med J. 1990; 169:692-6.

30. Sato Y, Toma H, Takara M, Kiyuna S, Shiroma Y. Seroespidemiological studies on the concomitance of strongyloidiasis with T-cell leukemia viral infection in Okinawa, Japan. Japanese Journal of Parasitology 1990; 39(4):376-83.

31. Feitosa G, Bandeira AC, Sampaio DP, Badaró R, Brites C. High prevalence of giardiasis and strongyloidiasis among HIV-infected patients in Bahia, Brazil. Braz J Infect Dis. 2001; (6):339-44.

32. Newton MR, Rudge P, Cruickshank K. Magnetic resonance imaging in HTLV-I antibody positive patients. Lancet 1987; ii:514.

33. Tournier-Lasserve E, Gout D, Gessain A, et al. HTLV-I, brain abnormalities on magnetic resonance imaging, and relation with multiple sclerosis. Lancet 1987; ii:49-50.

34. Shibasaki H, Endo C, Kuroda Y, Kakigi R, Oda K, Komine S. Clinical picture of HTLV-I associated myelopathy. J Neurol Sci. 1988; 87:15-24.

35. Puccione-Söhler M, Chimelli L, Merçon M, et al. Pathological and virological assessment of acute HTLV-I-associated myelopathy complicated with encephalopathy and systemic inflamation. J Neurol Sci. 2003; 207:87-93.

36. Brites C, Weyll M, Pedroso C, Badaró R. Severe and Norwegian scabies are strongly associated with retroviral (HIV-1/HTLV-I) infection in Bahia, Brazil. AIDS 2002; 16(9):1292-3.

37. Sobesky M, Couppie P, Pradinaud R, et al. Coinfection with HIV and HTLV-I infection and survival in AIDS stage. French Guiana Study. GECVIG (Clinical HIV Study Group in Guiana). Presse Med. 2000 Mar 4; 29(8):413-6.

38. Brites C, Alencar R, Gusmão R, et al. Coinfection by HTLV-I is associated with a shorter survival among HIV-infected patients, in Bahia, Brazil. AIDS 2001 Oct 19; 15(15):2053-5.

39. Schechter M, Moulton L, Harrison L. HIV viral load and CD4+ lymphocyte counts in subjects coinfected by HIV and HTLV-1. J Acquir Immune Defic Syndrom Hum Retrovirol. 1997, 15:308-11. 